\title{
EKSISTENSI WANITA PEMECAH BATU ; ANTARA PERAN GENDER DAN ADAPTASI EKONOMI RUMAH TANGGA
}

\author{
Oryza Pneumatica I, Anisa Puspa Rani, Dwi Setiawan Chaniago,
}

\author{
Nuning Juniarsih, M. Rasyidi ${ }^{1}$
}

Abstrak: Pada masyarakat yang menganut sistem patriarkis, fungsi ekonomis keluarga diperankan oleh suami sebagai kepala rumah tangga, sedangkan, eksistensi diri seorang wanita identik dengan pekerjaan domestik dalam rumah tangga.Desakan kebutuhan ekonomi menjadi tantangan nyata yang harus disikapi oleh keluarga termasuk mendorong peran wanita untuk turut membantu fungsi ekonomi rumah tangga.Ketika wanita bekerja di luar rumah, khususnya sebagai pemecah batu maka terdapat pergeseran peran dan fungsi yang tentunya melekat pada pemahaman wanita tersebut sebagai bagian dari eksistensi diri. Adapun tujuan penelitian ini yakni ingin mengetahui bagaimana eksistensi diri yang dipahami oleh wanita pemecah batu dalam fungsi dan peran gender di dalam rumah tangga, dan bagaimana eksistensi diri yang dipahami oleh wanita pemecah batu dalam fungsi dan peran komplementer ekonomi rumah tangga. Penelitian ini menggunakan pendekatan teoritis eksistensi Jean Paul Sartre.Pendekatan penelitian yang dipergunakan adalah kualitatif. Hasil penelitian menunjukkan bahwa Eksistensi diri yang dipahami oleh wanita pemecah batu dalam fungsi dan peran gender di dalam rumah tangga adalah sebagai manifestasi perluasan fungsi-fungsi peran gender yang tidak saja terkonsentrasi pada peran konvensional mengatur penghasilan saja, namun disertai upaya-upaya untuk turut membantu peran ekonomi suami. Selain itu, eksistensi diri yang dipahami wanita pemecah batu dalam aktivitas ekonominya sebagai wujud pengabdian terhadap keluarga dengan turut meringankan beban suami serta melengkapi peran suami. Sedangkan Eksistensi diri yang dipahami oleh wanita pemecah batu dalam fungsi dan peran komplementer ekonomi rumah tangga yakni pertama sebagai manifestasi kontribusi istri dalam upaya menambah penghasilan

1 Dosen Program Studi Sosiologi Universitas Mataram 
keluarga dengan memanfaatkan waktu disela-sela peran sebagai ibu rumah tangga dengan cara yang produktif. Kedua Eksistensi kemandirian istri yang tidak semata bergantung kepada penghasilan suami dalam memenuhi kebutuhan keluarga.

Kata kunci : Eksistensi, Peran Gender, Pemecah Batu

\section{PENDAHULUAN}

Eksistensi merupakan refleksi dari kesadaran individu tentang diri dan lingkungan sosial yang ditunjukkan melalui suatu tindakan sosial. Proses aktualisasi eksistensi diri ditentukan oleh faktor internal dan eksternal. Proses internal merupakan dorongan dari dalam diri yang disebut dengan rasionalitas. Rasionalitas tersebut dapat berupa pertimbangan kebutuhan, manfaat, keinginan, dan pertimbangan internal individu, dari suatu tindakan yang dilakukan. Sedangkan faktor eksternal merupakan pemahaman yang diberikan oleh orang lain (interpretative meaning) terhadap suatu tindakan sosial. Proses ini bisa kita lihat dari munculnya reaksi atau tanggapan, berupa kesan suka atau tidak suka, label baik atau tidak baik, hingga sikap simpatik atau antipati terhadap suatu tindakan. Secara sosiologis, dinamika pertimbangan internal dan eksternal yang menentukan eksistensi diri berada dalam ruang konstruksi sosial yang dinamis, bergantung proses sosial.

Eksistensi diri individu dalam proses sosial dipengaruhi oleh kemampuan individu dalam beradaptasi menyesuaikan diri dengan berbagai kondisi sosial. Kondisi kemiskinan, keterbatasan peluang kerja, keterbatasan keterampilan ditengah kebutuhan hidup yang terus meningkat mendorong individu harus mampu beradaptasi agar mampu mempertahankan eksistensi diri.Kondisi tersebut terjadi pada berbagai tataran kehidupan, tidak terkecuali dalam kehidupan keluarga khususnya yang kurang mampu. Bagi keluarga kurang mampu di pedesaan kondisi ekonomi saat ini cenderung dilematis di tengah lapangan pekerjaan sektor pertanian yang cenderung stagnan, sedangkan untuk beralih ke sektor industri belum memiliki keterampilan yang memadai ${ }^{2}$

Keluarga kurang mampu untuk dapat mempertahankan eksistensi hidup layak, paling tidak memerlukan adaptasi dalam hal pengeluaran dan pemasukan rumah tangga.Adaptasi pengeluaran tersebut dilakukan melalui usaha-usaha efesiensi dan penghematan pengeluaran rumah tangga dengan skala prioritas.Sedangkan adaptasi

2 Yustika, Erani. Ahmad. 2003. Negara VS Kaum Miskin. Pustaka Pelajar: Yogyakarta. 
pemasukan dilakukan dengan mengoptimalkan sumber-sumber pendapatan dengan mendayagunakan peran anggota keluarga dalam menambah pemasukan rumah tangga. Pada umumnya pendayagunaan peran anggota keluarga, tetap mempertimbangkan jenis pekerjaan (occupations) yang tidak memerlukan keahlian dan keterampilan khusus namun tetap memiliki nilai ekonomis.

Melihat kondisi perekonomian di perdesaan yang memiliki kecenderungan pergeseran dari sektor agraris ke sektor industrialis, maka pemilihan jenis pekerjaan menjadi sangat urgens dilakukan.Dengan kondisi keterampilan yang terbatas, dan keahlian yang masih bercorak agraris serta keterbatasan modal maka sektor informal dengan pekerjaan di luar bidang pertanian (off farm employment) menjadi salah satu pilihan bidang pekerjaan yang ditekuni.Peluang kerja off farm employmentbergantung dengan kondisi ketersedian sumber daya alam yang memiliki nilai ekonomis, serta pemanfaatannya tidak memerlukan modal yang besar.Salah satu jenis pekerjaan off farm employmentyang memungkinkan untuk melibatkan peran anggota keluarga serta banyak dilakukan pada masyarakat Kabupaten Lombok Barat adalah bekerja sebagai pemecah batu.

Pekerjaan pemecah batu di Kabupaten Lombok Barat banyak digeluti oleh masyarakat sesuai dengan fisiografis wilayahnya yang banyak memiliki perbukitan batu. Hal tersebut sebagaimana ditemui pada masyarakat di Desa Tanah Beak, Kecamatan Narmada.Menariknya aktivitas ekonomi pemecah batu banyak melibatkan peran wanita yang juga berstatus sebagai ibu rumah tangga.Keterlibatan wanita dalam pemenuhan fungsi ekonomis rumah tangga, secara sosiologis berimplikasi terhadap banyak aspek. Hal tersebut tidak hanya menyangkut peran komplementer wanita dalam menunjang ekonomi keluarga,

Pada masyarakat yang menganut sistem patriarkis, fungsi ekonomis jelas diperankan oleh ayah sebagai kepala rumah tangga.Hal tersebut tidak terlepas dari peran ekonomi yang menghasilkan legitimasi kontrol bagi seorang kepala rumah tangga dalam menentukan berbagai pengambilan keputusan di dalam rumah tangga. Sedangkan dalam konstruksi umum masyarakat, eksistensi diri seorang wanita identik dengan pekerjaan domestik dalam rumah tangga. Di sisi lain, desakan kebutuhan ekonomi menjadi tantangan nyata yang harus disikapi oleh keluarga termasuk mendorong peran wanita untuk turut membantu fungsi ekonomi rumah tangga. Ketika wanita bekerja di luar rumah, khususnya sebagai pemecah batu maka terdapat pergeseran peran dan fungsi yang tentunya melekat pada pemahaman wanita tersebut sebagai bagian dari eksistensi diri. Adapun eksistensi diri yang ditekankan menjadi fokus permasalahan pada penelitian ini yakni eksistensi peran dan fungsi wanita dalam kaitannya dengan pergeseran peran gender di dalam rumah tangga, serta 
eksistensi diri dalam kaitannya dengan peran dan fungsi komplementer ekonomi rumah tangga.

Secara umum tujuan penelitian ini untuk mengeksplorasi eksistensi diri wanita pemecah batu berdasarkan rasionalitas personalnya, yang terdiri atas:

1. Mengetahui secara mendalam eksistensi diri yang dipahami oleh wanita pemecah batu dalam fungsi dan peran gender di dalam rumah tangga.

2. Mengetahui eksistensi diri yang dipahami oleh wanita pemecah batu dalam fungsi dan peran komplementer ekonomi rumah tangga.

\section{TEORI EKSISTENSIALISME JEAN PAUL SARTRE}

Selain referensi penelitian terdahulu, digunakan pula teori pendukung yang akan digunakan sebagai alat bantu analisis dalam penelitian ini. Pemikiran eksistensialisme Jean Paul Sartre seringkali menjadi rujukan dalam memahami realitas hegemonik antara pemikiran mainstream dan anti-maintream, kelompok superior dan kelompok imperior, serta kelompok dominasi dan subordinasi. Secara singkat pemikiran eksistensialisme berusaha melakukan pembebasan eksistensi individu yang terkekang oleh suatu pemikiran dan struktur yang relative dan menghegemoni kesadaran individu.Bagi penganut eksistensialisme, manusia bukanlah subjek bagi atau ditentukan oleh aturan-aturan sosial yang ada di dalam masyarakat, dalam artian standarisasi tindakan individu tidak dapat membenarkan tindakannya dengan merujuk pada sesuatu yang berada di luar dirinya ${ }^{3}$.Pemikiran eksistensialisme ini berkembang di abad 20 di Prancis dan Jerman sebagai respon terhadap kondisi hegemoni yang muncul di era poskolonial.

Eksistensi dimanifestasikan melalui aksi dan individu adalah apa yang individu tersebut lakukan (Sartre, 1943). Penganut eksistensialis meyakini bahwa diri adalah pusat filsafat yang esensial dan sebagai sumber kekuasaan yang terlegitimasi.Hingga dikenal istilah "Saya ada, maka saya berfikir" yang merupakan pandangan ekstrim tentang rasionalitas Descartes yang menyatakan "Saya berpikir maka saya ada". Esensi dari pemikiran eksistensialisme bahwa pengakuan atas keberadaan individu sebagai obyek yang memiliki eksistensi diri melalui kesadaran yang langsung dan subyektif yang terkadang jauh lebih mendasar dibandingkan dengan pemahaman umum masyarakat tentang suatu perbuatan.

Eksistensialisme merupakan kritik Sartre terhadap struktur yang deterministik sebagai penentu tindakan manusia. Dalam kehidupan sehari-hari yang melibatkan proses konstruksi sosial seringkali ditemui berbagai kondisi yang mengandung

3 Craib, Ian. 1992. Teori-teori Sosial Modern. Jakarta: CV. Rajawali 
pengekangan terhadap eksistensi diri individu. Pada hal idealnya manusia menggenggam takdir di tangannya sendiri ${ }^{4}$.Labelisasi peran dan fungsi wanita untuk pekerjaan konvensional rumah tangga, dan laki-laki yang mesti mengerjakan urusan di luar rumah merupakan pemahaman unilateral yang mendiskreditkan peran perempuan. Pemikiran tersebut tentu tidak akan bermasalah ketika kebutuhan ekonomis di dalam rumah tangga terpenuhi, namun dalam kondisi keterbatasan ekonomi rumah tangga, dan wanita dalam posisi potensial untuk berkontribusi maka dengan dasar kebutuhan subyektif tersebut setiap wanita memiliki hak untuk bertindak sebagai bagian dari eksistensi diri.

Eksistensialisme sebagai paham pembebasan bukan berarti anti-mainstream atau anti terhadap berbagai konsensus konvensionalyang telah mapan.Eksistensialisme merupakan kritik terhadap penganut Marxis yang secara dogmatis menekankan peran dan kekuasaan structural sehingga mengeleminir humanisme ${ }^{5}$.Lebih jauh, eksistensialisme memberikan ruang bagi individu untuk bertindak berdasarkan kondisi dan kebutuhan subyektif diri.Artinya tidak ada realitas maupun pengetahuan yang dapat dipisahkan dari subyek yang memahami dan mengetahuinya.Untuk itu, penganut eksistensialisme percaya bahwa kebenaran merupakan pengalaman subyektif tentang hidup dan konsekwensi logis yang dipahami atas tindakan subyektif tersebut.

Eksistensi berbeda dengan esensi.Eksistensi berarti keadaan akrual yang terjadi dalam ruang dan waktu, dan bereksistensi yakni menciptakan diri sendiri secara aktif dengan berbuat dan merencanakan sesuatu atas dasar keinginan subyektif diri. Sedangkan esensi adalah sesuatu yang membedakan sesuatu benda dengan benda yang lain dengan corak berbeda, atau sebagaimana adanya. Oleh karena itu, pendukung eksistensialisme mengarah pada upaya menemukan kebebasan dengan merujuk pada suatu fakta, dimana suatu benda atau boyek tidak akan memiliki makna apa-apa tanpa keterlibatan pemahaman dan pengalaman individu. Sehingga individu merupakan titik central dalam relasi yang terbangun dalam proses sosial sebagai subyek dan pengalaman. Menurut Sartre, Cara berda manusia melalui dua cara, yakni L'etre-en-soi (berada pada dirinya) dan L'etre-pour-soi (berada untuk dirinya).

Pada perspektif Sartre konsep tentang berada memiliki perbedaan yang mendasar antara L'etre-en-soi (berada pada dirinya) dan L'etre-pour-soi (berada untuk dirinya).L'etre-en-soi merupakan berada dalam arti pasif, individu menempatkan sesuatu yang merupakan hasil konstruksi sosial tentang makna-makna segala sesuatu tanpa memahami arti keberadaan tersebut berdasarkan kebutuhan diri,

4 Ritzer, George. 2010. Teori Sosial Modern. Yogyakarta: Kreasi Wacana.

5 Loc.cit 
dengan kata lain segala sesuatu yang berda pada diri merupakan hasil cengkokan dari obyek eksternal. Sebaliknya L'etre-pour-soimengandung makna berada pada diri ketika individu memahami dan menyadari makna dan arti segala sesuatu berdasarkan kebutuhan dan peran diri secara subyektif.

Kebebasan adalah esensi individu, individu yang bebas menciptakan dirinya melalui serangkaian sikap yang sejalan dengan tujuan yang ingin dicapai. Dengan kebebasan itu pula indiviu dapat mengatur, memilih, dan memberikan makna pada realiatas yang ia ciptakan. Oleh karena itu, eksistensi bermakna keterbukaan, sekaligus membedakan makna keberadaan individu dengan benda-benda yang keberadaannya sekaligus esensi.Sedangkan pada individu, keberadaannya terdiri atas eksistensi yang mendahului esensi.Eksistensi individu dengan segala pertimbangan subyektif diri harus terbebaskan dengan prasyarat tintdakan tersebut membawa manfaat pada pada diri serta berkontribusi terhadap eksistensi diri.Individu dengan rasionalitasnya bebas memaknai suatu tindakan yang menunjukkan eksistensi dirinya. Eksistensi diri setiap individu tidaklah sama, bergantung pada kemampuan refleksi diri individu tersebut. Dalam hal ini kemampuan adaptif manusia sejauh didasari pada kesadaran akan kebutuhan diri dalam memperjuangkan eksistensi diri dan subyektivitas diri akan suatu tindakan.

\section{Peran dan Fungsi Gender dalam Rumah Tangga}

Gender memiliki arti peran dan fungsi sosial yang terbentuk berdasarkan jenis kelamin.Konsep gender harus dibedakan dengan seks (jenis kelamin). Pengertian jenis kelamin merupakan pensifatan atau pembagian dua jenis kelamin manusia yang ditentukan secara biologis. Sedangkan gender itu sendiri merupakan suatu sifat yang melekat pada kaum laki-laki maupun perempuan yang dikonstruksi secara sosial maupun kultural. Misalnya saja wanita dikenal lemah lembut, emosional, keibuan, sedangkan laki-laki di anggap kuat, dan rasional. Sifat-sifat tersebut pada dasarnya dapat dipertukarkan, sehingga segala hal yang dapat dipertukarkan antara sifat lakilaki dan perempuan yang dapat berubah dari waktu ke waktu serta berada dari tempat ke tempat lainnya itulah yang dikenal dengan konsep gender ${ }^{6}$.

Konsep gender itu sendiri seringkali sulit dipahami dalam masyarakat. Masyarakat masih menilai seseorang berdasarkan jenis kelamin, misalnya saja dalam hal pekerjaan. Laki-laki yang di anggap kuat memiliki tanggung jawab sebagai kepala rumah tangga untuk menafkahi keluarga sedangkan perempuan yang dianggap memiliki sifat penyayang lebih pantas untuk bekerja di rumab seperti merawat anak,

6 Fakih, Mansour. 2012. Analisis Gender dan Transformasi Sosial. Yogyakarta: Pustaka Pelajar. 
memasak dan mengurus rumah. Hal ini menunjukkan bahwa laki-laki berperan penting dalam sektor publik dan perempuan bekerja dalam sektor domestik. Jika kita berbicara tentang keluarga maka dapat dipahami bahwa keluarga merupakan unit terkecil didalam masyarakat yang terdiri dari ayah ibu dan anak. Keluarga sebagai sebuah sistem akan mempunyai tugas seperti sistem sosial lain yang ada dalam masyarakat, seperti menjalankan tugas-tugas, pencapaian tujuan, integrasi dan solidaritas serta pola kesinambungan atau pemeliharaan keluarga.

Keluarga memiliki fungsi-fungi yang harus terpenuhi diantaranya adalah fungsi afeksi, fungsi sosialisasi, fungsi perlindungan, fungsi rekreasi, dan juga fungsi ekonomi. Fungsi afeksi merupakan fungsi pemenuhan kasih sayang bagi setiap anggota keluarga. Kedua orang tua memiliki kewajiban memberikan kasih sayang bagi anak dan juga semua anggota keluarga. Fungsi afeksi ini sangat berpengaruh pada keharmonisan keluarga itu sendiri. Fungsi yang kedua adalah fungsi sosialisasi dan masih memiliki keterkaitan dengan fungsi afeksi yang berfungsi sebagai penanaman nilai-nilai dan norma bagi anak-anak sehingga nantinya mereka siap untuk menjadi bagian dari masyarakat. Fungsi ketiga yaitu fungsi perlindungan, fungsi ini berkaitan dengan memberikan rasa nyaman dan aman bagi setiap anggota keluarga. Selanjutnya fungsi ke empat yaitu fungsi rekreasi. Pemenuhan kebutuhan tidak hanya seputar kebutuhan sandang dan papan melainkan juga kehutuhan rohani yang berkaitan dengan liburan atau rekreasi. Hal ini penting karena aktivitas diluar rumah seperti bekerja di kantor dan sekolah terkadang membuat anggota keluarga merasa penat sehingga membutuhkan rekreasi. Rekreasi juga bisa mempererat hubungan antara anggota keluarga. Fungsi terakhir yaitu fungsi ekonomi, fungsi ini menjadi penunjang bagi kesejahteraan sebuah keluarga. Orang tua memiliki kewajiban untuk memberikan nafkah dan kehidupan yang layak bagi keluarga terutama anak.

Berbicara mengenai fungsi ekonomi pada keluarga, maka akan sangat jelas bahwa demi keberlangsungan sebuah keluarga perlu adanya pemenuhan kebutuhan dalam hal produksi, distribusi dan konsumsi. Kebutuhan sebuah keluarga tidak hanya berupa pemenuhan kebutuhan konsumsi melainkan juga kebutuhan lain yaitu biaya hidup seperti untuk transportasi, biaya pendidikan dan lain sebagainya. Pada masyarakat tradisional, pembagian kerja dalam kelurga masih berdasarkan jenis kelamin sehingga fungsi ekonomi ini dibebankan kepada laki-laki sebagai kepala kelurga untuk bekerja dan memenuhi semua kebutuhan tersebut. Sedangkan dalam masyarakat modern yang telah mengalami banyak perubahan hal ini tidak terjadi lagi, laki-laki dan perempuan memiliki kesempatan yang sama untuk dapat bekerja di sektor publik baik formal maupun informal. 
Kebutuhan dan biaya hidup yang semakin meningkat menjadikan perempuan tidak hanya berdiam diri di rumah tetapi sudah mulai berfikir untuk bekerja dan membantu perekonomian keluarga. Bagi keluarga dengan ekonomi menengah ke atas, perempuan yang bekerja memiliki kemungkinan untuk dapat memilih jenis pekerjaan yang mereka sukai dan tidak tertekan dengan kebutuhan akan uang. Sedangkan perempuan yang berada di kalangan menengah ke bawah atau keluarga miskin cenderung harus bekerja dan mendapatkan pekerjaan yang kurang menyenangkan. Pendidikan yang tidak memadai dan kurangnya keterampilan membuat perempuan ini memiliki kesulitan untuk mendapatkan pekerjaan yang layak. Mereka tertekan pada kondisi ekonomi keluarga yang mengharuskan mereka membantu untuk memnuhi kebutuhan hidup sehari-hari. Hal ini dapat ditemui pada wanita pemecah batu di Desa Tanah Beak, Kecamatan Narmada.

\section{Sektor Informal, dan Peluang Kerja Off Farm Employment}

Perkembangan sektor informal merupakan proses adaptif ekonomi yang muncul dalam menyikapi proses pembangunan. Sektor informal oleh beberapa ahli dikategorisasikan dalam beberapa pengertian yakni sektor informal sebagai gejala transisi dalam proses pembangunan di negara berkembang, dimana sektor informal merupakan tahapan yang harus dilalui untuk mencapai tahapan yang lebih modern. Pemikiran tersebut merepresentasikan proses perubahan evolusioner linier sebagaimana yang digaungkan oleh penganut modernisasi. Selain itu, sektor informal juga dianggap sebagai gejala adanya ketidakseimbangan kebijaksanaa pembangunan yang lebih berorientasi pada sektor modern atau industrial ${ }^{7}$

Sektor informal lahir ketika desakan kebutuhan ekonomi masyarakat, kondisi kemiskinan, dan ketimpangan penyerapan tenaga kerja di sektor formal tiddak optimal. Di sisi lain, adaptasi ekonomi tersebut muncul dengan mengoptimalkan sumber daya yang ada, dan potensial untuk dikembangkan. Dalam penelitian ini, yang dimaksud dengan sektor informal adalah jenis pekerjaan yang digeluti oleh masyarakat di luar sektor formal dan pertanian, dengan mendayagunakan sumber daya alam yang tersedia (batu) dan memanfaatkan anggota rumah tangga sebagai pekerjanya.

Kondisi dilematis pada masyarakat perdesaan dimana sektor pertanian cenderung mengalami stagnasi dan bahkan terdegradasi oleh sektor industri dan jasa mendorong perubahan ekonomi masyarakat agar dapat memenuhi kebutuhan keluarga.Sebaliknya, di saat sektor industri dan jasa di perdesaan semakin berkembang,

7 Effendi, Noer.Tadjuddin. 1995. Sumber Daya Manusia, Peluang Kerja dan Kemiskinan. Yogyakarta: Tiara Wacana. 
namun dengan kualifikasi dan keahlian yang terstandarisasi, tidak semua tenaga kerja dapat terserap pada sektor tersebut. Ketika jumlah serapan tenaga kerja sektor industri terbatas, maka peluang kerja akan tersubstitusi ke dalam bentuk pekerjaan-pekerjaan penunjang yang tidak memerlukan modal dan keterampilan khusus (mengandalkan tenaga).

Pada dasarnya keterbatasan serapan tenaga kerja di sektor industri disebabkan oleh dua faktor yakni pertama industry yang diharapkan mampu menyerap tenaga kerja belum dapat berkembang secara optimal, kedua, pendidikan yang diharapkan dapat melahirkan tenaga kerja yang terampil sesuai dengan permintaan dan perkembangan pasar kerja belum berfungsi sebagaimana mestinya. Menurut Bromley dan dan Gerry dalam sektor informal terdapat pekerja dengan status meliputi, buruh tidak tetap, pekerja sub-kontrak atau borongan yang dikerjakan rumah tangga atau dalam usaha kecil, pekerja yang tergantung pada bahan, alat atau tempat yang disewa atau diperoleh melalui kredit, dan pekerja usaha sendiri yang tidak terikat kepada usaha lain dalam pembelian, permodalan atau penjualan hasil produksi ${ }^{8}$.

Munculnya sektor informal di perdesaan merupakan indikasi bahwa kesempatan kerja yang ada di perdesaan belum sebanding dengan jumlah serapan tenaga kerja yang ideal.Oleh sebab itu, muncul sektor informal sebagai bagian dari katup penyelamat ekonomi dan penambah penghasilan keluarga. Namun, meskipun sektor informal di perdesaan dapat mengurangi angka pengangguran dengan menyerap sejumlah tenaga kerja, akan tetapi sektor tersebut beberapa diantaranya masih menawarkan pendapatan dengan hasil yang terbatas ${ }^{9}$.

Menurut Thomas sektor informal dan aktivitas (ekonomi) informal memiliki perbedaan.Adapun aktivitas ekonomi informal terbagi menjadi empat sektor produksi yakni pertama, sektor rumah tangga (bousehold sector) yakni memproduksi barang dan jasa yang kemudian di distribusikan dan di konsumsi dalam sektor rumah tangga. Kedua, sektor informal yang berciri sebagai produsen skala kecil; menggunakan tenaga kerja sendiri dalam memproduksi barang atau jasa.Ketiga, sektor irregular (irregular sector) yakni aktivitas ekonomi dengan sebagian tindakan-tindakan yang melanggar atau bertentangan dengan regulasi formal atau illegal.Keempat sektor criminal (criminal sector) yakni aktivitas ekonomi melawan hukum ${ }^{10}$.

Kondisi perdesaan yang mengarah pada semakin terbatasnya peluang kerja pada sektor pertanian mendorong adaptasi paling tidak dalam dua bentuk, yakni memilih sektor perkerjaan lain di dalam desa, ataupun melakukan urbanisasi ke perkotaan.

\footnotetext{
8 Loc.cit

9 Yustika, Erani. Ahmad. Op.cit

10 Loc.cit
} 
Bekerja di luar sektor pertanian di pedesaan memerukan stimulus agar lahirnya sektor off farm employment. Off farm employment merujuk pada aktivitas ekonomi atau pekerjaan di luar sektor pertanian yang digeluti oleh masyarakat di perdesaan. Menurut Tadjuddin, Off farm employmentdapat didefinisikan dalam beberapa pengertian, yakni pertama mengacu pada jenis pekerjaan yang sifatnya bukan pertanian baik milik sendiri atau milik orang lain. Berdasarkan lokasinya Off farm employmentyakni pekerjaan yang dilakukan di luar pertanian tetapi masih dilakukan di lingkungan pedesaan atau di kota.

Perkembangan off farm employmentmemiliki pertalian yang erat dengan kondisi serapan tenaga kerja sektor ekonomi pertanian.Menurut Sand ${ }^{11}$ terdapat empat tingkatan jalinan antara perkembangan sektor pertanian dan off farm employment. Pertama disebut dengan tingkat keseimbangan rendah, yakni ketika ekonomi perdesaan didominasi sektor pertanian, mobilitas ekonomi rendah, minim teknologi, dalam kondisi seperti ini sektor off farm employmentberguna dalam menambah penghasilan keluarga namun dengan penghasilan yang terbatas, dan bersifat musiman. Kedua, kondisi sektor pertanian yang mengalami peningkatan seiring terbukanya mobilitas ekonomi desa-kota, serapan teknologi baru, dan meningkatnya produktivitas, dalam kondisi ini aktivitas perekonomian masih kurang produktif, namun cenderung mengalami peningkatan. Ketiga, transformasi sektor pertanian ke industri yang ditandai dengan meningkatnya peluang kerja namun di sisi lain membentuk standarisasi kualifikasi pekerja sehingga tenaga kerja yang tidak terakomodir beralih ke sektor off farm employment. Pada tahap ini off farm employmentmengalami perkembangan dan semakin kompetitif. Keempat, kondisi intensitas serapan tenaga kerja sektor informal menurun dan beralih pada sektor Off farm employmentdengan penghasilan yang lebih tinggi di banding sektor pertanian.

Keterbatasan peluang kerja sektor pertanian dan industri, pertumbuhan angka pencari kerja dan tekanan kebutuhan mendorng orang untuk bekerja di luar sektor pertanian (non farm employment.) Menurut Khada, (1982) sektor non farm employment memiliki tiga fungsi yakni, pertama sektor non farm employmentberpotensi untuk menciptakan peluang kerja bagi tenaga kerja perdesaan tanpa dukungan modal yang besar. Kedua berkemampuan untuk menstimulus pertumbuhan ekonomi pedesaan karena dapat sebagai sumber penghasilan utama untuk rumah tangga kurang mampu. Ketiga sektor non farm employmentmemiliki efek jalinan yang kuat pada pengembangan pertanian dan industry ${ }^{12}$

11 Effendi, Tadjuddin Noer.1995. Sumber Daya Manusia, Peluang Kerja, dan Kemiskinan. Yogyakarta: PT. Tiara Wacana.

12 Loc.cit 


\section{Deskripsi Aktivitas Ekonomi Pemecah Batu}

Aktivitas ekonomi wanita pemecah batu Di Desa Tanak Beak merupakan aktivitas sampingan ibu rumah tangga dalam menambah pemasukan ekonomi keluarga.Aktivitas pemecah batu merupakan salah satu peluang kerja yang muncul di luar sektor pertanian (off farm employment) sebagai wujud adaptasi ekonomi masyarakat dalam memenuhi kebutuhan rumah tangga.Keterbatasan penghasilan ekonomi keluarga di sektor pertanian dan buruh lepas mendorong ibu rumah tangga untuk mencari sumber-sumber pemasukan baru.Aktivitas yang bersifat fleksibel dan lokasi kerja yang berada di sekitar tempat tinggal menjadi pendukung aktivitas ekonomi komplementer keluarga tersebut untuk dilakukan.

Sektor off farm employmentpada wanita pemecah batu di Tanak Beak memiliki pertalian yang kuat seiring dengan kebutuhan industri yang memerlukan pasokan pecahan batu sebagai salah satu bahan dasar bangunan.Sebelum tahun 2012, kebutuhan batu-batu besar sebagai bahan dasar aktivitas ekonomi pemecah batu didapat melalui sungai yang mengalir di sepanjang Desa Tanak Beak.Semakin massifnya aktivitas pemecah batu di Desa Tanak Beak berdampak pada semakin berkurangnya ketersediaan batu di sungai si sekitar lingkungan tempat tinggal warga. Oleh karena itu, sejak tahun 2013 kebutuhan batu besar pada umumnya dipasok dari luar desa melalui agen atau bos pemilik modal yang mengantar ke lokasi kerja pemecah batu. Adapun deskripsi aktivitas pemecah batu sebagaimana diungkapkan oleh informan berikut ini;

"Dalem proses begaweana totok batu lek daerah tanak beak, inak-inak sak milu gawek totok batu niki, mauk batu lengan kokok sak, arak deket sekitaran dese tanak beak atau batu niki tebait lengan agen sak epe batumasyarakat lek dese niki begawean banye jadi burub totok batu doang. Saebagian luek batu niki te totok jadi ukuran kodek sampe bau te jualisik. bos / agen" (Suriah, 35 tahun, wawancara tanggal 15 Oktober 2015).

Artinya : Dalam proses kerja pemecah batu di Desa tanak Beak, ibu-ibu ada yang mendapatkan batu dari sungai disekitar desa dan ada yang didapat melalui agen yang mengantarkan batu dan ibu-ibu bekerja sebagai buruh pemecah batu. Setelah batu berukuran kecil diberikan kepada bos. 
Berdasarkan informasi yang diungkapkan informan tersebut menunjukkan aktivitas ekonomi wanita pemecah batu dimana ibu-ibu berperan sebagai buruh pemecah batu.Keterbatasan bahan dasar batu di Desa Tanak Beak, berdampak pada pola pemenuhan kebutuhan bahan dasar batu yang di suplai oleh pemilik modal dari luar desa. Batu-batu yang telah dipecahkan kemudian diambil kembali oleh agen untuk kemudian di jual ke kota untuk kebutuhan bahan bangunan. Hal tersebut sekaligus mempertegas status wanita pemecah batu sebagai buruh pekerja.

Dalam aktivitas ekonomi pemecah batu, wanita pemecah batu mendapatkan upah dari hasil kerja berdasarkan jumlah batu yang dihasilkan. Biasanya untuk satu ember batu kecil yang berhasil dipecahkan akan diganjar upah sebesar Rp. 2.000. Sedangkan penghasilan yang didapat dalam aktivitas pemecah batu sangat bergantung kepada kemampuan tenaga dan waktu yang tersedia. Adapun gambaran produktivitas pemecah batu setiap harinya sebagaimana diungkapkan oleh informan berikut ini;

"Tte cume mank. lime ember batu dalam sejelo no, langan jam baluk kelemak sampe jam lime bian, terus ite te beli seember no cume due ribu doang, jari sejelo no ite mauk sepulu ribu, kadang lamu te pacu ance kuat jak, mauk te sampe pituk ember dalme sejelo no, jari tergantung ketekunan te doang, ance kuat te" (Murni, 27 tabun, wawancara tanggal 12 Oktober 2015).

Artinya : Para ibu ibu hanya mendapatkan lima ember batu per harinya, dan harag per embernya hanya Rp.2 000 , paling banya mereka daptkan hanyalah tujuh ember, dari jam 8:00 pagi sampai jam 17: sore, jadi bias disimpulkan bahwa penghasilan para ibu ibu pemecah batu hanyalah Rp.10.000 per harinya atau paling banyak mencapai Rp. 14.000 .

Informasi yang diungkapkan informan tersebut menggambarkan bahwa penghasilan yang didapat oleh wanita pemecah batu relatif bergantung dengan kemampuan tenaga dan waktu yang tersedia. Murni misalnya, secara usia tergolong masih muda maksimal sehari hanya mampu memecah batu sebanyak 7 ember selama 9 jam kerja. Namun hasil tersebut jarang ia peroleh mengingat alokasi waktu yang dicurahkan pada aktivitas pemecah batu tidak memungkinkan untuk ia lakukan. Sebagai ibu rumah tangga, murni harus bisa membagi waktu dengan perannya di keluarga.sehingga maksimal rata-rata sehari Murni hanya bisa mendapatkan 5 ember perhari. Dengan rata-rata kerja selama satu bulan sebanyak 25 hari, maka setiap bulan Murni mendapatkan penghasilan tambahan sebesar Rp. 250.000. 
Jumlah penghasilan wanita pemecah batu memang terbilang kecil.Namun demikian hasil tersebut sangat berarti dalam menambah pemasukan dalam memenuhi kebutuhan keluarga.Untuk alasan tersebut pula aktivitas pemecah batu tersebut terus dilakukan.Rutinitas aktivitas pemecah batu yang terbangun dengan agen dapat pula menjadi katup penyelamat bagi kondisi ekonomi keluarga.Dalam kondisi terdesak, pemecah batu bisa mengambil upah di muka.Namun jumlahnya hutang yang diberikan tidak besar.Hanya sesuai dengan jumlah rata-rata batu yang dihasilkan setiap hari.Hal tersebut berlaku pula bagi agen pemilik batu.Terkadang dalam kondisi uang penjualan batu belum dibayar pembeli, maka upah pembayaran batu hasil pecahan ibu-ibu ditunda pembayarannya.

Keterbatasan keterampilan dan modal menjadikan aktivitas pemecah batu sebagai satu-satunya opsi bagi ibu rumah tangga untuk dapat menambah penghasilan keluarga.Meskipun pendapatan yang dihasilkan relatif kecil dan resiko kerja yang besar namun aktivitas tersebut terus dilakukan. Hal tersebut sebagaimana diungkapkan oleh informan berikut ini;

"Soalne jak iye doang saq bau tejariang pegawean, lamun saq lain jak kadu kepeng doang jari modal te berusahe, laguq lamun mene kan ndek te kadu ape-ape Cuma kadu modal tenage doang, jari ye doang bau te gaweq, lamun jari petani atau pedagang jak pade doang, terus maukte endak ndekn penoq, jelap te lelah endah, jari bagusan doang idapne lamun begawean leq batu ne, karing te tokol doang sambil pecah batu, maukte endak cukup ye sebanding kance pegaweante saq cume tokol doang sambil pecah batu no "(Kartini, 48 tabun, wawancara tanggal 15 Oktober 2015).

Artinya : karena itu adalah satu-satunya pekerjaan yang tidak perlu menggunakan modal uang, cukup hanya menggunakan modal tenaga saja, kalau bekerja sebagai petani atau berdagang tetap harus menggunakan modal uang sebagai modal awalnya dan hasilnya pun kadang tak menentu dan tak seberapa. Tetapi kalau bekrja jadi pemecah batu ini enak, hanya perlu duduk saja sambil memecah batu sebanyak-banyaknya, itupun bisa diselingi dengan saling berkumpul sesame teman pemecah batu, sehingga capeknya tidak terlalu terasa, dan tidak seperti sedang bekerja.Dan hasil yang didaptkan juga lumayan cukup apalagi kerjanya pemecah batu seperti saya yang hanya tinggal duduk saja sambil memecahnya.

Aktivitas ekonomi wanita pemecah batu terus menunjukkan eksistensinya paling tidak dengan tiga pertimbangan yakni pertama aktivitas ekonomi yang dilakukan dapat menyerap tenaga kerja lepas dengan sistem kerja yang fleksibel, tanpa modal 
dan keterampilan khusus.kedua, hasil kerja yang mampu menstimulus pendapatan ekonomi keluarga, khususnya bagi keluarga kurang mampu. Ketiga, perputaran ekonomi dan pembangunan perkotaan yang memerlukan bahan dasar batu dalam pembangunan.Adapun ciri utama aktivitas ekonomi wanita pemecah batu adalah tidak memperhitungkan tenaga sebagai sumber modal utama dalam mendukung aktivitas ekonomi tersebut.

\section{Adaptasi dan Eksistensi Peran Gender Wanita Pemecah Batu}

\section{Adaptasi Peran Gender Dalam Keluarga}

Pada masyarakat yang bercorak perdesaan, terdapat pembagian yang jelas dalam pengaturan peran keluarga.Peran utama ibu di dalam rumah tangga yang terkonsentrasi pada urusan konvensional yakni edukasi, dan afeksi.Sedangkan peran ekonomi dominan diperankan oleh suami sebagai kepala keluarga sekaligus dalam menjamin fungsi proteksi di dalam keluarga.Peran konvensional tersebut dalam aktivitas ekonomi wanita pemecah batu turut mengalami perubahan, khususnya dalam pemenuhan fungsi ekonomi keluarga.Keterbatasan pemasukan, dan besarnya tingkat kebutuhan keluarga mendorong keluarga dalam mengoptimalkan peran anggota keluarga di luar ayah, untuk turut menambah sumber pemasukan.

Aktivitas ibu rumah tangga bekerja sebagai pemecah batu merupakan salah satu bentuk adaptasi peran gender di dalam keluarga. Desakan kebutuhan ekonomi berdampak pada transformasi peran gender istri yang tidak lagi semata berfokus pada pengaturan keuangan keluarga, lebih jauh istri terdorong untuk turut membantu menambah sumber pemasukan keluarga melalui pekerjaan yang memungkinkan dilakukan. Hal tersebut sebagaimana diungkapkan informan berikut ini;

"Ye ntan te jari tulung semame, soalne kan anak tiang wah tame sekolah endah, jari keperluan jak. kadu sekolab no kan semakin lueq, mbe ndek man jari mangan te bilang jelo, lamun te cumaq andelan teenage semamaq doang jaq ndekn bau cukup, jari mele ndek. mele harus te milu begawean ampoqn bau cukup kepeng ite jari kebutuhan sejelo"(Zaitun, 32 tabun, wawancara tanggal 12 Oktober 2015).

Artinya : Untuk membantu suami saya mencari uang, apalagi anak kami sekarang sudah mulai sekolah, kebutuhannya semakin meningkat begitu juga dengan kebutuhan pokok yang semakin meningkat juga, jadi kalau hanya mnegharpkan penghasilan dari suami saja maka tidak akan cukup untuk biaya makan dan 
hidup sehari-hari, jadi saya harus membantunya mendapatkan tambahan uang untuk biaya hidup sekeluarga.

Informasi yang diungkapkan oleh informan tersebut menggambarkan adaptasi peran istri di dalam keluarga melalui aktivitas pemecah batu.Hal tersebut memungkinkan dilakukan dengan berbagai pertimbangan bidang ekonomi yang digeluti dapat dilakukan tanpa mengganggu peran ibu di dalam rumah tangga. Aktivitas pemecah batu menjadi pilihan dalam menambah penghasilan keluarga diiiringi dengan peningkatan peran istri di dalam rumah tangga.

Peran gender adalah hasil konstruksi sosial masyarakat. sejak kecil individu diajari tentang fungsi dan peran gender sesuai dengan kelaziman atau nilai persifi dalam masyarakat. peran dan fungsi gender sebagai hasil konstruksi sosial dapat dilihat dari adaptasi peran gender pada wanita pemecah batu yang menariknya tidak hanya tercipta setelah berumah tangga. Pada wanita pemecah batu di Desa Tanak Beak, Paling tidak mereka telah dipersiapkan untuk dapat beradaptasi dalam melakukan peran sebagai istri dalam keluarga.

Dalam realitas wanita pemecah batu di Desa Tanak Beak, paling tidak faktor penyebab munculnya adaptasi peran gender di dalam keluarga didorong oleh empat kondisi yakni pertama pekerjaan sebagai pemecah batu merupakan pekerjaan yang telah lama digeluti yakni sejak sebelum menikah.Kendati demikian, motif tersebut tetaplah bentuk adaptasi peran gender dalam keluarga, sebab aktivitas tersebut didasari oleh kesadaran bahwa wanita (sebelum menikah) telah diajarkan untuk dapat berkontribusi dalam ekonomi keluarga. Menurut Arini, salah satu penyebab ia bekerja sebagai pemacah batu sebagaimana ungkapannya berikut ini;

"Laek aku milu kance dengan taok ke, dengan toak ke endah dengan sak ndek, bedoe jarin aku harus ke bantu dengan toak ke jarin sampe nane aku wab terbiase notok batu sengak sak ne pegawean sak mudak te boyak" (Arini, 24 tabun.Wawancara tanggal 15 Oktober 2016).

Artinya :Dulu saya ikut dengan orang tua saya, orang tua saya orang yang tidak punya, saya harus membantu orang tua saya dan juga saya terbiasa sampai sekarang. Dan ini pekerjaan yang paling mudah didapat.

Ungkapan informan tersebut sebagaimana diungkapkan juga oleh informan yakni Rehan (40 tahun), Murni (27 Tahun), Rita (19 tahun), dan Rohmatun (25 tahun). Hal tersebut mempertegas rasionalitas yang mendasari adaptasi peran gender dalam keluarga merupakan hasil bentukan dari pengalaman sosial wanita pemecah 
batu bahkan dimasa pra-menikah. Hal tersebut terus dan tetap dipertahankan sebagai sebuah rasionalitas yang berorientasi pada nilai perlunya seorang istri turut membantu suami dalam menopang ekonomi keluarga. Menariknya, wanita pemecah batu yang memiliki rasionalitas demikian umumnya berada pada kategori usia muda dan memiliki pengalaman sosial dimana orang tua mereka telah bekerja sebagai pemecah batu.

Kedua, adaptasi peran gender wanita pemecah batu didorong oleh tuntutan ekonomi.meningkatnya kebutuhan yang tidak berbanding lurus dengan peningkatan penghasilan suami. Pekerjaan suami yang umumnya bekerja di sektor pertanian, khususnya buruh tani menghasilkan penghasilan yang belum mampu memenuhi kebutuhan ekonomi keluarg.Kebutuhan bumbu dapur, biaya pendidikan anak, serta kemungkinan peningkatan kebutuhan keluarga yang tidak bisa terpenuhi hanya melalui penghasilan suami mendorong adaptasi peran gender istri dalam keluarga melalui perluasan peran gender di bidang ekonomi.bekerja sebagai pemecah batu merupakan pilihan rasional istri untuk dapat membantu meningkatkan penghasilan keluarga. Hal tersebut sebagaimana diungkapkan oleh Zaitun (32 tahun), berikut ini;

"....Ye ntan te jari tulung semame, soalne kan anak tiang wah tame sekolab endah, jari keperluan jak kadu sekolab no kan semakin lueq, mbe ndek man jari mangan te bilang jelo, lamun te cumaq andelan teenage semamaq doang jaq ndekn bau cukup, jari mele ndek mele harus te milu begawean ampoqn bau cukup kepeng ite jari kebutuban sejelo,.. (Zaitun, 32 Tahun Wawancara Tanggal 15 Oktober 2016).

Artinya : ,..Untuk membantu suami saya mencari uang, apalagi anak kami sekarang sudah mulai sekolah, kebutuhannya semakin meningkat begitu juga dengan kebutuhan pokok yang semakin meningkat juga, jadi kalau hanya mnegharapkan penghasilan dari suami saja maka tidak akan cukup untuk biaya makan dan hidup sehari-hari, jadi saya harus membantunya mendapatkan tambahan uang untuk biaya hidup sekeluarga.

Ungkapan Zaitun tersebut merupakan wujud rasionalitas yang melatarbelakangi adaptasi peran gender istri dalam upaya turut membantu kewajiban suami dalam menopang perekonomian keluarga. Hal tersebut sangat logis, mengingat kondisi perekonomian keluarga yang tidka sepenuhnya bisa dipenuhi suami. Perluasan peran gender istri dalam menopang kebutuhan ekonomi merupakan wujud komitmen istri 
terhadap keluarga. hal tersebut sekaligus menandai fleksibelnya peran-peran yang dimainkan oleh anggota keluarga dalam aktivitas pemenuhan ekonomi.

Ketiga, kondisi keterbatasan keterampilan dan pendidikan yang dimiliki menjadi salah satu dasar rasionalitas yang mendorong adaptasi peran gender wanita pemecah batu.Pekerjaan sebagai pemecah batu tidak hanya disebabkan oleh tuntutan ekonomi keluarga.lebih jauh, bidang tersebut turut digeluti akibat keterampilan yang dimiliki masih sangat terbatas. Keterbatasan keterampilan, serapan dan ketersediaan pekerjaan di sektor agraris yang terbatas, dan minimnya modal yang dimiliki menjadikan aktivitas pekerjaan sebagai pemecah batu sebagai salah satu pilihan pekerjaan yang paling rasional. Hal tersebut sebagaimana diungkapkan oleh Murni (27 tahun) berikut ini;

"...Ndak arak pegawean sak. lain, sak murak mauk kepeng marak pegawean ne. (Murni, 27 tahun. Wawancara tanggal 14 Oktober 2016).

Artinya :Tidak ada pekerjkaan lain yang mudah mendapatkan uang seperti pemecah batu ini.

Ungkapan informan tersebut menjelaskan bahwa adaptasi peran gender wanita pemecah batu didasari atas pertimbangan jenis pekerjaan pemecah batu yang tidak memerlukan keahlian khusus dan tanpa modal.Kendati tanpa keterampilan khusus, aktivitas tersebut dapat dilakukan dengan tanpa mengorbankan peran di dalam keluarga, namun dengan penghasilan yang relative stabil.Apalagi aktivitas memecah batu dilakukan di lingkungan yang berdekatan dengan tempat tinggal.

Keempat, adaptasi peran gender juga didorong oleh upaya istri dalam mengoptimalkan waktu luang di dalam rumah tangga.Peran utama istri didalam keluarga yang terkonsentrasi pada urusan domestik rumah tangga seperti memasak, mencuci dan mengurus keperluan keluarga lainnya adalah pekerjaan rutin namun tidak terlalu menyita waktu.Dengan manajemen waktu yang baik, pekerjaan rumah tangga tersebut dapat diselesaikan dan masih menyisakan waktu yang cukup.Kondisi keterbatasan penghasilan dalam keluarga, dan keterbatasan dalam pemenuhan kebutuhan harian telah mendorong wanita pemecah batu untuk keluar dari peran gender utama dalam mengurus kebutuhan rumah tangga ke urusan ekonomi.Desakan ekonomi telah mendorong istri untuk kreatif dan produktif dalam memanfaatkan waktu luang, yakni melalui aktivitas memecahkan batu. Hal tersebut sebagaimana diungkapkan oleh Suriah (35 tahun) berikut ini; 
"...Totok batu niki gawek gunaan waktu luang” (Suriah, 35 tahun.Wawancara tanggal 15 oktober 2016).

Artinya : pekerjaan pemecah batu ini untuk memanfaatkan waktu luang.

Ungkapan Suriah tersebut menggambarkan bahwa pemanfaatan waktu luang merupakan salah satu dasar yang mendorong adaptasi peran gender istri dalam aktivitas ekonomi. Pekerjaan sebagai pemecah batu tersebut merupakan manifestasi dari rasionalitas istri dalam memanfaatkan waktu luang agar dapat produktif dan kontributif terhadap persoalan ekonomi keluarga.

Bekerja sebagai pemecah batu bukanlah pilihan individual semata. Lebih jauh sebagai wujud komitmen istri dalam menopang kebutuhan ekonomi keluarga tanpa mengorbankan peran-peran gender di dalam rumah tangga. Pilihan tersebut juga didukung oleh anggota keluarga.Hal tersebut tidak terlepas dari kesadaran anggota keluarga tentang perlu pendapatan tambahan untuk menopang ekonomi keluarga.Dengan bekerja sebagai pemecah batu, ada banyak pengeluaran kecil yang bisa ditutupi oleh istri seperti belanja harian anak, belanja kebutuhan dapur, dan menabung untuk kebutuhan sekolah anak.Hal tersebut sangat membantu ekonomi keluarga sebab pemenuhan kebutuhan tidak terkonsentrasi pada penghasilan suami semata.

Dukungan keluarga terhadap aktivitas ekonomi pemecah batu didasari oleh kesadaran perlunya penghasilan tambahan bagi keluarga.Aktivitas pemecah batu sebisa mungkin dilakukan ketika tanggungjawab sebagai ibu rumah tangga telah terlaksanakan. Wanita pemecah batu tidak akan memulai pekerjaan sebelum kebutuhan pagi hari keluarga terpenuhi. Aktivitas tersebut praktis dimulai ketika suami telah turun untuk bekerja, serta anak telah pergi sekolah.Sehingga aktivitas pemecah batu juga bagian dari pemanfaatan waktu luang agar lebih produktif.

Peran ganda yang dijalankan oleh wanita pemecah batu berimplikasi pada penyesuaian-penyesuaian peran dalam keluarga.Meskipun tidak ada perubahan peran secara signifikan, namun konsekwensi aktivitas istri sebagai pemecah batu turut dirasakan oleh anggota keluarga. Hal tersebut sebagaimana diungkapkan oleh informan berikut ini;

"lamun anaq tiang wahn sili gitaq tiang begawean maraq mene, ye sili waktun uleq sekolah laguq ndek man araq nasi kadu jaqn mangan, terus lamun jaq bekedeq ndek narak kelambi siqn jak besalin, soalne kan tiang ndek man sempet tiang mopok, jari meno wah, laguq sue-sue jak baune ngerti soalne kan taoqn lamun tiang begawean endah siq jari kadu 
iye doing, terus sekediq endah waktu kance anaq tiang, soalne kan tiang uleq begawean sore, jari ndek naraq sempet waktu kance anaq tiang, pas kemalem doang araq kesempatan kumpul bareng-bareng" (Kartini, 48 tabun, wawancara tanggal 14 Oktober 2016)

Artinya : Kalau anak pernah, apalagi kalau pulang sekolah dia belum makan siang, dan saya tidak sempat memasak untuknya jadi terpaksa harus beli di warung, kemudian saat tidak ada baju yang dipakai untuk main kerana saya belum sempat mencuci, jadi dia marah sekali, terus sedikit waktu yang bisa saya habiskan dengan anak saya, soalnya kan saya pergi kerja pagi dan pulangnya sore, kalau siang saya hanya pulang sebentar untuk istirahat, dan waktu itu anak saya pergi main-main jadi sedikit waktunya.

Informasi informan tersebut menunjukkan bahwa terdapat perubahan dalam kualitas interaksi antar anggota keluarga di dalam rumah tangga.Hal tersebut tidak terlepas dari besarnya alokasi waktu yang dicurahkan bagi ibu rumah tangga yang bekerja sebagai pemecah batu.Namun demikian, manfaat ekonomis yang didapat sebagai pemecah batu mendorong aktivitas tersebut terus dilakukan.

\section{Eksistensi Peran Gender Dalam Keluarga}

Eksistensi peran gender dalam keluarga mengalami pergeseran. Bagi wanita pemecah batu, terdapat kepuasan ketika ia mampu membantu peran suami dalam memenuhi kebutuhan harian keluarga. Tambahan peran tersebut tidak dipandang sebagai beban, namun komitmen istri dalam membantu memecahkan persoalan ekonomi di dalam keluarga.Tekanan ekonomi telah mendorong istri untuk dapat keluar dari peran konvensional mengurus rumah tangga menjadi salah satu penopang ekonomi keluarga di luar suami.Peran ganda tersebut cenderung dipahami sebagai peran komplementer (pelengkap).Bagi ibu-ibu pemecah batu, pengorbanannya bekerja merupakan wujud dedikasinya kepada keluarga.apalagi pekerjaan tersebut dilakukan disela-sela perannya sebagai ibu rumah tangga. Hal tersebut sebagaimana diungkapkan oleh informan berikut;

"Endek, tiang gawek pegawean bale juluk, iye tugas utame jadi senine. misalne meriap, nyapu dll.selama tiang mampu kance arak keinginan tiang jak merubah perekonomian keluarge kance endek jak menganggu peran tiang jadi ibu rumah tangga. menurut tiang biase doang" (Uswatun, 32 tahun. Wawancara Tanggal 14 Oktober). 
Artinya : Tidak, tentu saja tidak karena dalam mejalankan peran sebagai seororang istri haruslah tetap pada tugas yang pertama yakni untuk melakukan pekerjaan sebagai ibu rumah tangga pada umumnya yakni memasak , memebersihkan rumah, dll. Selama saya mampu dan ada keinginan untuk merubah perekonomian keluarga dan tidak menganggu peran sebagai ibu rumah tangga tentu tidak menganggu dan saya merasa biasa aja.

Ungkapan informan tersebut mempertegas eksistensi peran gender wanita pemecah batu di rumah tangga. Tekanan ekonomi di dalam keluarga mendorong peran istri di rumah semakin luas.Bagi wanita pemecah batu hal tersebut menjadi sebuah kewajaran permisif ketika istri bekerja di luar rumah untuk membantu pekerjaan suami dalam pemenuhan ekonomi keluarga.Peran ganda yang dilakukan tersebut tidak dianggap sebagai beban tambahan, melainkan sebuah dorongan moral bagi istri untuk membantu perekonomian keluarga.

Eksistensi peran gender wanita pemecah batu bersifat komplementer. Artinya aktivitas ekonomi yang dikerjakan setelah kewajiban sebagai ibu rumah tangga telah terlaksanakan. Peran gender sebagai ibu rumah tangga adalah prioritas utama. Sedangkan perluasan peran gender dengan bekerja sebagai pemecah batu merupakan peran pelengkap yang dilakukan setelah peran utama sebagai ibu rumah tangga telah terlaksana. Hal tersebut sebagaimana diungkapkan oleh informan berikut;

"Pegawean urus bale lebih sike te pejuluk, berembe-berembe kan tugas senine tetep urus bale" (Sabariah, 55 tahun, wawancara tanggal 15 oktober 2016).

Artinya : pekerjaan rumah tangga yang lebih utama, bagaimanapun tugas seorang istri tetap aja harus melaksanakan dan menyelesaikan pekerjaan rumah dahulu.

Ungkapan informan tersebut menggambarkan bahwa bagi wanita pemecah batu pekerjaan di rumah tangga merupakan peran utama.Dikarenakan aktivitas ekonomi wanita pemecah batu dilakukan setelah peran sebagai ibu rumah tangga terlaksana. Maka bagi ibu-ibu pemecah batu tidak merasa takut mendapatkan cibiran atatu tanggapan negatif masyarakat.Bagi wanita pemecah batu, perluasan peran gender yang dilakukannya merupakan tindakan mulia.Bahkan pekerjaan yang dilakukan terbilang keras yakni sebagai pemecah batu juga dianggap sebagai komitmen kuat istri di dalam keluarga.Hal tersebut berlaku umum bagi masyarakat di Desa Tanak Beak yang pada umumnya banyak bekerja sebagai wanita pemecah batu. 
Setiap harinya, wanita pemecah batu menghabiskan 7-8 jam untuk bekerja. Aktivitas pemecah batu dilakukan mulai jam 07:00 pagi. Namun aktivitas memulai bekerja sebagai pemecah batu tersebut umumnya dilakukan setelah anak berangkat sekolah dan suami telah pergi bekerja.Artinya waktu yang diluangkan untuk bekerja adalah waktu luang dalam kegiatan rumah tangga yang dimanfaatkan dengan memecah batu. Biasanya wanita pemecah batu jam 11:30 menghentikan kegiatannya dan pulang ke rumah untuk menyiapkan kebutuhan makan siang dan beristirahat. Aktivitas wanita pemecah batu dimulai kembali jam 13:00 hingga 16:00 sore. Rutinitas tersebut terus dilakukan dengan rata-rata bekerja 25 hari dalam sebulan.

Prinsipnya aktivitas ekonomi pemecah batu dilakukan untuk mengurangi beban suami dalam memenuhi kebutuhan keluarga.Dengan bekerja sebagai pemecah batu, terdapat penghasilan yang dapat dialokasikan untuk keperluan rumah tangga.Selain itu, ketika wanita pemecah batu memiliki penghasilan, kebutuhan harian rumah tangga tidak hanya bergantung kepada suami. Sehingga perluasan peran gender wanita pemecah batu tersebut merupakan perwujudan kemandirian istri. Hal tersebut sebagaimana diungkapkan oleh informan berikut ini;

"Aku ndek ngerase berembe rembe, mungkin cuman ngerase mandiri doang sengak baunt bantu semame walaupun sekedik", (Arini, 24 tahun.Wawancara tanggal 15 oktober 2016).

Artinya :Saya tidak merasakan apa apa, mungkin hanya merasa mandiri sajalah kalau kita bisa membantu suami walaupun tidak seberapa.

Ungkapan informan tersebut menunjukkan bahwa terdapat perluasan makna eksistensi diri wanita pemecah batu dalam peran gender dalam rumah tangga. Sikap kemandirian, komitmen dan dedikasi istri kepada keluarga.eksistensi peran gender tidak terbatas pada pelaksanaan tugas konvensional rumah tangga semata, atau melakukan pekerjaan yang diperintahkan oleh suami saja. Namun eksistensi peran gender juga beradaptasi terhadap kebutuhan ekonomi keluarga. Perluasan peran istri dalam aktivitas wanita pemecah batu ditandai dengan bentuk eksistensi peran gender yang meliputi dua aspek, yakni pertama eksistensi peran gender wanita yang mandiri, dan kedua eksistensi peran gender wanita sebagai wujud pengabdian terhadap keluarga.

Eksistensi peran gender wanita yang dipahami sebagai bentuk kemandirian didasari oleh pemikiran dan pemaknaan diri wanita pemecah batu yang lebih otonom dalam keluarga. Dalam peran konvensional sebagai ibu rumah tangga, peran gender 
dalam bidang ekonomi hanya sebatas mengatur keuangan, berbeda ketika mereka bekerja sebagai pemecah batu.Penghasilan yang didapat dikontrol oleh wanita pemecah batu sendiri.Peruntukan penghasilan tersebut masih ditujukan untuk kebutuhan keluarga seperti belanja bumbu dapur, menambah jajan anak, hingga kebutuhan menabung.Jadi Produktifitas wanita pemecah batu tersebut tidak dinilai dari besaran hasil pekerjaan yang diperoleh, namun lebih kepada proporsi keleluasaan istri dalam mengontrol penghasilan yang dimiliki untuk ikut berkontribusi dalam memenuhi kebutuhan keluarga.

Eksistensi peran gender wanita pemecah batu berupa bentuk pengabdian terhadap keluarga merupakan hasil perluasan peran gender yang sangat penting. Kesadaran akan keterbatasan penghasilan dan pemasukan suami dalam memenuhi kebutuhan keluarga disikapi dengan menunjukkan eksistensi diri wanita pemecah batu dengan dedikasi dan pengabdian. Eksistensi peran gender tersebut dilakukan untuk turut meringankan beban ekonomi suami, menjamin keberlanjutan pemenuhan kebutuhan keluarga, dan melengkapi peran ekonomi suami. Aktivitas ekonomi wanita pemecah batu dilakukan sebatas melengkapi peran ekonomi yang secara esensial masih ditopang oleh suami.

\section{Adaptasi dan Eksistensi Peran Ekonomi Wanita Pemecah Batu}

\section{Adaptasi Peran Ekonomi Dalam Keluarga}

Kebutuhan ekonomi keluarga pada dasarnya dipenuhi dari sumber utama yakni penghasilan bulanan.Pada masyarakat desa yang cenderung tradisional, sumber penghasilan utama diusahakan oleh suami.Penghasilan yang didapat tersebut didistribusikan oleh suami kepada istri.Istri kemudian dapat mengalokasikan pemasukan suami tersebut kedalam berbagai pos-pos kebutuhan rumah tangga. Pola seperti ini umumnya akan bertahan ketika penghasilan suami dapat memenuhi keseluruhan kebutuhan keluarga.

Pola ekonomi konvensional dimana suami memiliki peran sentral dalam mengupayakan penghasilan memiliki karakter utama dimana peran istri hanya dalam mengelola keuangan rumah tangga.Sedangkan kontrol utama masih berada pada suami.Pada kasus wanita pemecah batu, peran istri sebagai pengatur ekonomi keluarga mengalami perluasan disebabkan desakan kebutuhan ekonomi yang tidak sepenuhnya dapat dipenuhi oleh suami.Salah satu pilihan rasional yang dapat dilakukan adalah melakukan adaptasi ekonomi keluarga, baik dalam hal penghematan pengeluaran, maupun menambah sumber pendapatan keluarga. 
Adaptasi peran ekonomi wanita pemecah batu disebabkan oleh dua kondisi utama, yakni upaya pemenuhan kebutuhan keluarga, dan munculnya kesadaran untuk memanfaatkan waktu disela-sela peran sebagai ibu rumah tangga dengan cara yang produktif. Pertimbangan pemenuhan kebutuhan keluarga didasari oleh keterbatasan sumber penghasilan yang dimiliki keluarga.Dalam kondisi konvensional dimana sumber utama penghasilan berasal dari suami.Namun dalam kondisi keterbatasan, istri perlu turut menopang kebutuhan keluarga tersebut. Kebutuhan keluarga yang turut mendasari adaptasi ekonomi wanita pemecah batu meliputi pemenuhan kebutuhan dapur, uang belanja anak sekolah dan kebutuhan harian lain.

Kondisi keterbatasan ekonomi juga disikapi dengan orientasi dalam pemanfaatan waktu luang didalam keluarga lebih berorientasi produktif. Aktivitas pemecah batu yang dilakukan di lingkungan sekitar tempat tinggal, dan pekerjaan yang dilakukan secara bersama sambil bercengkrama dengan rekan seprofesi yang merupakan tetangga semakin mendukung proses adaptasi ekonomi dalam aktivitas pemecah batu. Dengan memanfaatkan waktu luang setelah peran sebagai ibu rumah tangga terpenuhi, paling tidak istri memiliki 6-8 jam waktu yang dapat dimanfaatkan untuk bekerja sebagai pemecah batu.Waktu luang tersebut turut berkontribusi terhadap produktifitas istri di dalam keluarga dalam perannya membantu suami memenuhi kebutuhan rumah tangga.

Aktivitas pekerja wanita pemecah batu merupakan bentuk adaptasi peran ekonomi istri dalam keluarga.adaptasi tersebut didasari oleh memperbesar peluang untuk dapatmemenuhikebutuhan keluarga, sekaligus bagiistri mendapatan pemasukan serta kontrol terhadap penghasilan tersebut. Kontrol terhadap penghasilan sebagai wanita pemecah batu sangat penting dalam meningkatkan kemandirian ekonomi istri. Hal tersebut sebagaimana informasi yang diungkapkan oleh informan berikut ini;

"sengak ndek narak sak te gawek, ketimbang momot lek bale ndek te mauk ape ape mending te totok batu maukt kadu belanje kepengen. Kadu te mbeli kebutuhan pawon marak sbie sak lain lain endh, kance jari kepeng belanje ndek te mungkin ngandelan semame doang" (Jumisah, 65 tahun. Wawancara tanggal 15 oktober 2016).

Artinya :Karena tidak ada yang kita mau kerjakan. Ketimbang diam dirumah tidak dapat apa apa mending keluar mecah batu dapat saya pakai belanja uangnya.Untuk membeli kebutuhan dapur seperti membeli cabe dan lain lain. Dan menjadi uang jajan juga karena tidak mungkin kita dapat mengandalkan suami saja. 
Ungkapan informan tersebut menggambarkan makna aktivitas ekonomi wanita pemecah batu yang merupakan adaptasi ekonomi istri.Adaptasi tersebut didasari oleh rasionalitas wanita pemecah batu dalam melihat pemenuhan kebutuhan, pemanfaatan waktu luang, serta memperoleh penghasilan yang dapat dikontrol disamping berperan sebagai komplementer ekonomi suami di dalam rumah tangga.Adaptasi ekonomi yang bersifat komplementer tidak mereduksi peran ekonomi suami, melainkan memperkuat fungsi ekonomi keluarga termasuk memperbear kontrol ekonomi istri di dalam keluarga.

Peningkatan rasionalitas yang mendorong adaptasi tindakan ekonomi wanita pemecah batu didasari pertimbangan individual tanpa didorong oleh pihak lain. Jenis pekerjaan yang dipilih disesuaikan dengan alokasi waktu dan peran yang dilaksanakan di rumah tangga.Selain itu, bentuk pekerjaan sebagai pemecah batu didasari pertimbangan keterampilan dan teknik yang tidak terlalu tinggi.Teknik pekerjaan dalam menentukan aktivitas ekonomi sebagai pemecah batu lebih didasari oleh pertimbangan jenis pekerjaan yang dilakukan tidak mengganggu peran sebagai ibu rumah tangga.

Motif individual dalam aktivitas wanita pemecah batu memperbesar peluang kontrol terhadap penghasilan yang dihasilkan.Penghasilan yang dihasilakan dialokasikan secara otonom oleh wanita pemecah batu.Kendati demikian pengalokasian sumber penghasilan masih berorientasi pada kebutuhan ekonomi keluarga.kontrol terhadap penghasilan yang didapatkan memperbesar kemandirian istri di dalam rumah tangga.

Besaran waktu yang dialokasikan oleh wanita pemecah batu dalam aktivitas ekonomi selama 7-8 jam perhari.Waktu tersebut dilakukan disela-sela peran sebagai ibu rumah tangga.Aktivitas pemecah batu pagi hari dimulai pagi hari setelah anak berangkat sekolah dan suami berangkat bekerja. Pada waktu jam makan siang dan anak pulang sekolah, biasanya wanita pemecah batu pulang ke rumah untuk menjalankan peran sebagai ibu rumah tangga. Kemudian aktivitas tersebut berlanjut hingga sore hari.

\section{Eksistensi Peran Ekonomi Dalam Keluarga}

Eksistensi peran ekonomi wanita pemecah batu terbentuk atas kebutuhan ekonomi keluarga yang tidak mampu sepenuhnya ditopang oleh penghasilan suami. Selain manfaat ekonomi yang didapat berupa peningkatan penghasilan keluarga, perluasan peran ekonomi pada wanita pemecah batu berdampak pada menguatnya peran ekonomi serta meningkatkan kontrol terhadap penghasilan dan kemandirian di 
dalam rumah tangga.Hal tersebut berdampak pada semakin fleksibelnya peran-peran di rumah tangga dikarenakan adanya penyesuaian dalam fungsi ekonomi keluarga.

Eksistensi ekonomi wanita pemecah batu paling tidak didasari oleh dua bentuk rasionalitas.Yang pertama, aktivitas pemecah batu dilakukan untuk menambah penghasilan keluarga. Hal tersebut sebagaimana diungkapkan oleh informan berikut ini;

"ndak selame ite senine ngendeng jok semame, ite endh te begawean tulung semame pete kepeng, adek sak seimbang saling tulung. Ndk te mauk beng anaka jari te belanje atau ndk te tao penubi kebutuban ekonomi te, sengat gaji semame te sekedik endab" (Budiatun, 27 tabun. Wawancara tanggal 14 Oktober 2016).

Artinya : Karena tidak selamanya kita sebagai seorang istri harus terus dan selalu meminta kepada suami, sebagai isti yang baik kta juga harus ikut membantu mencari nafkah dalam keluarga, melihat pendapatan suami masih minim. Tidak bisa memenuhi kebutuhan sehari hari keluarga, karena pendapatan suami yang masih minim, jadi penghasilan dari istri juga sangat diperlukan untuk membantu memenuhi kebutuan ekonomi keluarga.

Ungkapan informan tersebut mempertegas upaya-upaya optimalisasi peningkatan pendapatan keluarga yang turut ditopang oleh wanita pemecah batu. Peran ekonomi keluarga yang turut diemban oleh istri meminimalisir kegagalan keluarga dalam memenuhi kebutuhan harian.Sifat komplementer ekonomi wanita pemecah batu tersebut menjadi penanda besarnya komitmen peran istri di dalam keluarga.

Aktivitas bekerja wanita pemecah batu tersebut tidak terlepas dari semakin berkurangnya penghasilan yang didapat dari suami yang umumnya bekerja sebagai buruh bangunan dan buruh tani.Keterbatasan kepemilikan sumberdaya dan keterampilan di luar sektor agraria mendorong peran istri untuk dapat bekerja di luar tuntutan peran konvensional sebagai ibu rumah tangga.Hal tersebut menjadi bagian dari pemenuhan kebutuhan harian (livelihoods).

Eksistensi peran ekonomi wanita pemecah batu juga didasari oleh rasionalitas dalam meningkatkan kemandirian istri yang tidak semata bergantung kepada penghasilan suami dalam memenuhi kebutuhan keluarga. Hal tersebut sebagaimana diungkapkan oleh informan berikut ini; 
"Memang kadang kita dapat duit belanja dikasi suami, tapi kadang ya kalau sekedar beli bumbu R. 1000-2.000 kalu minta dengan suami susah juga, beda kalau kita ada duit sedikit-sedikit dari mecah batu ni. Jadi kita bisa ada duit pegangan sendiri.Walaupun digunakan untuk keperluan keluarga juga.(Jumisah, 65 tahun.Wawancara tanggal 12 oktober 2016).

Informasi informan tersebut menunjukkan bahwa penghasilan yang didapat oleh wanita pemecah batu memiliki makna eksistensi sebagai penghasilan sendiri yang dapat dikelola secara otonom.Hal tersebut bertujuan untuk meminimalisir tingkat ketergantungan terhadap suami dalam hal pemenuhan kebutuhan keluarga. Di sisi lain juga berfungsi untuk meringankan beban ekonomi yang ditanggung suami. Dalam membantu menopang perekonomian keluarga tersebut, aktivitas bekerja sebagai pemecah batu dianggap sebagai pekerjaan yang paling rasional dan memungkinkan dikerjakan tanpa harus mengobankan peran sebagai ibu rumah tangga di dalam keluarga.

Peran komplementer istri dalam membantu perekonomian keluarga merupakan penanda utama eksistensi peran ekonomi wanita pemecah batu.Kesulitan dan desakan pemenuhan kebutuhan telah mendorong peran istri lebih fleksibel di dalam keluarga.Fleksibilitas peran istri dengan bekerja sebagai pemecah batu terbentuk dari desakan kebutuhan ekonomi. Istri menjabarkan perannya di dalam keluarga dengan turut membantu peran ekonomi yang ditopang suami. Untuk itu, eksistensi peran ekonomi wanita pemecah batu sangat penting dalam menjamin kebutuhan ekonomi keluarga.

\section{PENUTUP}

1. Eksistensi diri yang dipahami oleh wanita pemecah batu dalam fungsi dan peran gender di dalam rumah tangga adalah sebagai manifestasi perluasan fungsifungsi peran gender yang tidak saja terkonsentrasi pada peran konvensional mengatur penghasilan saja, namun disertai upaya-upaya untuk turut membantu peran ekonomi suami. Selain itu, eksistensi diri yang dipahami wanita pemecah batu dalam aktivitas ekonominya sebagai wujud pengabdian terhadap keluarga dengan turut meringankan beban suami serta melengkapi peran suami,

2. Eksistensi diri yang dipahami oleh wanita pemecah batu dalam fungsi dan peran komplementer ekonomi rumah tangga yakni pertama sebagai manifestasi kontribusi istri dalam upaya menambah penghasilan keluarga dengan memanfaatkan waktu disela-sela peran sebagai ibu rumah tangga dengan cara 
yang produktif. keduaEksistensi kemandirian istri yang tidak semata bergantung kepada penghasilan suami dalam memenuhi kebutuhan keluarga.

\section{DAFTAR PUSTAKA}

Afrizal. 2014. Metode Penelitian Kualitatif. Jakarta: Rajawali Pers

Agger, Ben. 2009. Teori Sosial Kritis (Kritik, Penerapan dan Implikasinya). Yogyakarta: Kreasi Wacana.

Effendi, Noer.Tadjuddin. 1995. Sumber Daya Manusia, Peluang Kerja dan Kemiskinan. Yogyakarta: Tiara Wacana.

Fakih, Mansour. 2012. Analisis Gender dan Transformasi Sosial. Yogyakarta: Pustaka Pelajar.

Goode, William J. 1995. Sosiologi Keluarga. Jakarta: Bumi Aksara

Ihromi. 2004. Bunga Rampai Sosiologi Keluarga. Jakarta: Obor Indonesia.

Jones, Pip. 2010. Pengantar Teori-Teori Sosial (Dari Teori Fungsional hingga Post-Modernisme). Jakarta: Obor Indonesia.

Khairuddin. 1992. Sosiologi Keluarga. Yogyakarta: Nur Cahaya.

Martono, Nanang. 2012. Sosiologi Perubahan Sosial (Perspektif Klasik, Modern, Posmodern, dan Poskolonial). Jakarta: Raja Grafindo.

Megawangi, Ratna. 1999. Membiarkan Berbeda? (Sudut Pandang Baru Tentang Relasi Gender). Bandung: Mizan.

Nugroho, Wahyu Budi. 2013. Orang Lain Adalah Neraka (Sosiologi Eksistensialisme Jean Paul Sartre). Yogyakarta: Pustaka Pelajar

Ritzer, George. 2010. Teori Sosial Modern. Yogyakarta: Kreasi Wacana.

Sajogyo, Pudjiwati. 1989. Sosiologi Pembangunan. Jakarta: IKIP Jakarta.

Soekanto, Soerjono. 2009. Sosiologi Keluarga.Jakarta: Rineka Cipta.

Suwarsono dan Alvin. 2013. Perubahan Sosial dan Pembangunan. Jakarta: LP3ES

Yustika, Erani. Ahmad. 2003. Negara VS Kaum Miskin. Pustaka Pelajar: Yogyakarta. 